\title{
Critical Success Factors of Technology Parks in Australia
}

\author{
Radwan Kharabsheh \\ Correspondence: Radwan Kharabsheh, Department of Business Adminstration, The Hashemite University, Zarqa, \\ PO Box 1181, Swelleh, Postal Code 11910, Jordan. Tel: 962-079-679-4421. E-mail: r.kharab@hu.edu.jo
}

\author{
Received: April 7, 2012 \\ Accepted: May 6, 2012 \\ Published: July 1, 2012 \\ doi:10.5539/ijef.v4n7p57 \\ URL: http://dx.doi.org/10.5539/ijef.v4n7p57
}

\begin{abstract}
Given the potential importance of technology parks, their complexity in terms of the scope of required investment and the growing interest of governments to use them as tools for creating sustainable development there is a pressing need for a better understanding of the critical success factors of these entities. However, Briggs and watt (2001) argued that the goal of many technology parks and the factors driving innovation success are still a mystery. It is also argued that the problem with analyzing technology parks is that recent studies analyze "the most celebrated case studies... to 'explain' their success". This study uses intensive interviewing to explore critical success factors of technology parks. The study identified the following factors: a culture of risk-taking "entrepreneurism", an autonomous park management, an enabling environment, a critical mass of companies, the presence of internationally renowned innovative companies, and finally a shared vision among the technology park stakeholders.
\end{abstract}

Keywords: success factors, technology parks, entrepreneurship, intellectual property, Australia

\section{Introduction}

The International Association of Science Parks (IASP) (2002) defined STPs as a property-based Initiative which: has operational links with universities, research centres and other institutions of higher education; is designed to encourage the formation and growth of knowledge-based industries or high value added tertiary firms, normally resident on site; has a steady management team actively engaged in fostering the transfer of technology and business to tenant organizations (Basile, 2011). While the Italian Association of Science and Technology Parks (APSTI) defines STPs as a "system for local development aimed at the promotion and support of: initiatives dedicated to scientific and technologic research; R\&D linkages; new innovative firms; innovative and competition for those firms operating in the geographical range of action of the park (Basile, 2011). Technology parks and incubation programs provide a mechanism to promote and stimulate commercial and industrial innovation (Venckuviene and Snieska, 2010), encourage re-industrialization and ensure sustainable regional development (Fazlzadeh and Moshiri, 2010; Akçomak, 2009). In addition to providing space for knowledge-based products, science and technology parks can house centres for scientific research, technological innovation and incubation, training, forecasting, as well as facilities for fairs, exhibitions and market development. They are formally linked (and usually physically close) to centres of technological excellence, universities and/or research centres.

Science parks are set up to facilitate commercialisation of technologies, stimulate development of technology-based SMEs and promote regional development (Malairaja and Zawadie, 2008). Firms that are located on a technology park geographically closer to each other than rival firms outside therefore, promoting the transmission of knowledge due to the lower costs of communication in a dense environment (Chan, Oerlemans and Pretorius, 2009). Within the park knowledge can be shared by formal and informal interpersonal or employee-related contacts amongst these firms or knowledge may be dispersed through relationships with local universities or other institutions of higher learning and/or research (Wolfe and Gertler, 2003). Thus a host academic institution, usually an Higher Education Institute (HEI), is often formally associated with a park (Chan, Oerlemans and Pretorius, 2009). Castells and Hall (1994) identified three reasons for establishing STPs: reindustrialization, regional development, and synergy creation. STPs are also received as the appropriate place for SMEs' growth. Peng and Heath (1996) developed a three-stage-choice model of firms' growth. Stage one deals with firms need for networking which requires trust and mutual understanding. Stage two deals with establishing a long-term relationship with other firms in order to obtain and sustain a competitive advantage. In stage three these firms create clusters whioch is the final and most developed stage of all.

More importantly, small and medium enterprises (SMEs), especially technology-based firms, have become an integral part of the regional and world economy development (Somsuk, Wonglimpiyarat and Laosirihongthong, 2012). Start-ups or new ventures usually carry the paradigms liability of newness and resource poverty (Lendner, 2004; 2007). For example, start-ups often lack technical and marketing capabilities, besides they also suffer from 
poor management, inability to find early stage financing, and high overheads (Hackett and Dilts, 2004). Thus, start-ups face the challenge of access to technology and financial resources and the commercialization capabilities necessary to bring a product to market (Lin et. al., 2011). This again brings into light the importance of STPs as a mechanism that could create supportive and entrepreneurial environments for technology-based start-ups, helping them to increase their survival rates (Somsuk, Wonglimpiyarat and Laosirihongthong, 2012). STPs offer start-ups and SMEs the technological support and services, and a solution in bridging the knowledge gap (Lalkaka, 2006) to help them develop their own viable businesses, by providing a resource-base necessary for supporting their development in early and critical stage.

However, technology parks and incubation programs are not always successful (Sun, Ni and Leung, 2007). For example, Colombo and Delmastro (2002) pointed out that "in spite of the diffusion of science parks in Europe, whether they have been successful or not in supporting new technology-based firms still is unclear". Some even concluded that technology parks in specific context might be a "technology fantasy" (Bakouros, Mardas, and Varsakelis, 2002). In addition, it is argued that the problem with analysing technology parks and cluster building is that recent studies analyse "the most celebrated case studies... to 'explain' their success" (Holbrook and Wolfe, 2002). Using intensive interviewing (Kvale, 1996; Reinharz, 1992) of four Australian technology parks' managers and managers of tenant firms this paper identified critical success factors for technology parks in Australia. The findings have practical implications for technology parks.

\section{Success Factors of Technology Parks}

The first and probably the most successful science park of all, the Stanford University Science Park in California, was founded in 1950 and in 1986 had already over 80 occupant companies employing over 26000 people (Basile, 2011). Business incubators diffused slowly between 1960 and 1970 in the US and were used a government tool urban economic revitalization (Somsuk, Wonglimpiyarat and Laosirihongthong (2012). However, between 1980 and 1990 there was an increase in the pace of diffusion of these incubators for three reasons: (Hackett and Dilts, 2004): the passage of the Bayh-Dole Act in the US Congress (in 1980), which stimulated the commercialization of university research (Rasmussen, 2008); an emphasis by the US legal system on the importance of innovation and intellectual property rights protection; and profit opportunities derived from the commercialization of basic research expanded (Somsuk, Wonglimpiyarat and Laosirihongthong (2012). In Britain the sector of property (specifically industrial/commercial property) which has become known as science parks has, since the early to mid-1980s, been one of near continuous growth (Gower and Harris, 1995). This growth of parks numbers in Britain was accompanied by an increase in their occupancy levels (Gower and Harris, 1995). Currently, the UNESCO estimates that there are more than 400 science parks worldwide and their number is still growing. The USA has the biggest number science parks - more than 150 science parks, followed by Japan with 111 science parks. China began developing science parks in the mid-1980s and now has around 100, 52 of which were approved by the national government and the remainder by local governments (UNESCO, 2012). The numbers will change if we consider the less general case of incubators. There are more than 4,000 incubators worldwide with more than 1,000 in the USA alone (Sun, Ni and Leung, 2007) with successful examples in almost all of developed countries.

However, some researchers questioned the assumed benefits of the science parks and incubation programmes (Chan and Lau, 2005). Colombo and Delmastro (2002) indicated that "in spite of the diffusion of science parks in Europe, whether they have been successful or not in supporting new technology-based firms still is unclear". There is little systematic research and empirical study on the relationship between critical success factors and the performance of incubation programme. How to improve the technology parks success rate and rate of the technological incubated entrepreneurs has become a critical issue. In addition, despite the considerable amount of research on the performance of incubation programmes (Mian, 1996, 1997; Sherman, 1999; Lindelof, Lofsten, 2002; Siegel, Westhead, and Wright, 2003; Bigliardi, et. al., 2005, Isaak, 2009); few studies examined related performance driven factors especially in Australia. For example, Smilor and Gill (1986) distinguished between success from the incubator and tenant firm perspectives. They identified ten critical success factors from the incubator perspective, and four from the tenant company perspective. Autto and Klofsten (1998) focused on configuration parameters such as: proximity to higher educational institutions, availability of on-site manufacturing facilities, competent science park management, accessibility of venture capital funding, and prudent tenant selection criteria. Others focused on the process aspect of STPs. Phan, Siegel and Wirhgt (2005) suggested that research should be analysed at four levels: the incubator level, the incubatee level, the entrepreneur level, and the system level. They also advocate connecting the four levels together for a comprehensive examination of success criteria.

Finally, economists argue that while Australia is a wealthy country (measured in GDP per capita) its position is declining relative to neighbouring Asian countries like Singapore and Hong Kong (Wood, 2003). Researchers cite 
among numerous factors a lack of strategic planning to thrust Australia into a globally competitive knowledge-based economy and Australia's failure to invest adequately in knowledge and knowledge-based industries (Wood, 2003).

\section{Methodology}

The study used semi structured intensive interviews and analysis of documents of technology parks managers, business development managers and marketing managers and mangers of tenant firms in the technology parks. In total 30 interviews were conducted. An interview is a directed conversation (Lofland and Lofland, 1984, 1995) that aims to gather information about the research topic and, as long as the discussion does not divagate too much, everything is permitted. Unlike structured interviews intensive interviewing relies on open-ended questions Bachman and Schutt (2007). Instead of asking the standard questions in a fixed order, intensive interviewers allow the specific content and order of questions to vary from one interviewee to another Bachman and Schutt (2007). The open and directed nature of intensive interviews allows the researcher to explore the participant's deep first-hand knowledge, focuses on lived experiences, and emphasises "making sense". It is an in-depth and intimate discussion beyond what ordinary conversational conventions and etiquette permit Hochschild (2009). The goal is to develop a comprehensive picture of the interviewees' background, attitudes, and actions, in their own terms; to "listen to people as they describe how they understand the worlds in which they live and work" (Rubin and Rubin, 1995: p. 3). It permits an in-depth exploration of a particular topic with a person who has had the relevant experiences (Charmaz, 2007: p.25) and therefore is a useful method for interpretive inquiry.

The process of data collection and analysis proceeded iteratively in accordance to the interpretive research tradition (Walsham, 2006). The study used thematic content analysis (Bardin, 2007) to analyse the data. Below are the discussion points:

1. How would you define success of a technology park? What makes one technology park more successful than another?

2. What factors influenced the success or failure of the technology park? What are the barriers to success? What are the enablers?

Hypotheses with regard to the determinants of success have been developed from the interviews and will be empirically tested using a survey instrument. This paper contains the findings from the interviews.

\subsection{Profile of the Participants}

There are four technology parks participating in this study. One is located in New South Wales and is the largest technology park in Australia with more than ninety tenant firms inhabiting the park. The second is located in Victoria and is considered to be one of the smallest technology parks in Australia with only numerous tenant firms. The other two parks were located in South Australia and one of them is the oldest technology park in Australia. In terms of management structures the parks varied in terms of reporting and management. Two parks reported to local government agencies, one reported to an Australian university and another had an independent management and was run as a private sector company.

\subsection{Key Informants}

The key informants in this study were: general managers, business development managers and marketing managers of the technology parks. Interviews were also conducted with managers of tenant firms located in the parks. A manager is contacted via phone and provided with a brief description of the study's rationale and objectives. The manager was assured that his/her identity and the identity of his organization were to remain confidential and that no one will have direct contact with the data collected except for the researcher.

\section{Defining Technology Park Success}

It is extremely difficult to quantify the financial and economic impact of a technology park, primarily because there is no established definition of success or a standard way to examine a company's effect on an economy (Drescher, 2001). Studies that have attempted to determine success or failure of technology parks tend to focus on two areas: benefits received by the park or the community and benefits received by businesses locating in the park. An even greater challenge, is defining success in a way that allows comparisons across different technology parks.

The interviews showed that the success of a technology park depends primarily on the body or the institution that is managing the park. That is the driving force behind the establishment and management of the technology park. In general, participants agreed that universities focused on: research, students training and creating intellectual property (IP) whereas government bodies focused: on technology transfer, job creation and economic development. In addition, participants noted that universities had little understanding of market mechanisms such the commercialization of IP and concept development and testing while government bodies treated technology parks as 
real estate developments. When the control and management of a technology park shifted from government to autonomous, private firm-like management the perception of success of the technology park changed to reflect the different stakeholders of the park itself.

While the participants agreed on the five major indicators of technology park success their emphasis on the importance of the different indicators varied. This reflected the different stakeholders involved in the technology park and their differing interests. Following are the five indicators:

\subsection{Technology Parks' Innovation and its Ability to Create IP}

One of the numerous and major roles a technology park plays is creating linkages between universities, research centres, research and development departments in companies and technologically based start ups. These linkages work on different levels: first, they allow start ups to have access to established laboratories and research bases that are otherwise expensive to build or rent. Secondly, they allow university students to have access to companies for training and an opportunity to pursue projects that can create IP. Thirdly, when a critical mass of companies exists in the technology park synergies exist and more IP is created. However, while the number of IPs created per year has been traditionally used to measure innovativeness it should be noted that this measure may not be appropriate for newly established STPs since the number of IPs would be generally low.

\subsection{The Ability of the Technology Park to Attract Funding}

Participants agreed that the ability of a technology park to attract funding was detrimental to its success. The funds that are collected are usually used for diverse purposes. Some of the purposes mentioned by participants included: intellectual property enhancement and "freedom to practice" analysis, prototype development and testing, market research and commercial assessment, feasibility studies for production, determination of regulatory and reimbursement pathways and finally preliminary business plans. One park manager explained that:

Our focus is to provide the pivotal support needed to advance technologies and bring about public interest in the technology so the companies can attract more funding and market interest.

\subsection{The Ability of the Technology to Create Value through Real Estate Development}

Technology parks are essentially a property-based development with a high-quality, physical environment in a park-like setting. They take advantage of proximity to sources of significant intellectual capital, conducive infrastructure and policy environment, and supports technology-based firms and state institutes in a managed area, thus facilitates interaction, technology development and economic growth. All participants agreed that a technology park success can be measured by its ability to create and develop real estate value. From the technology parks' management view this is important because real estate development is one of the factors that prospective tenants consider when choosing a park. A manager of a technology park explains:

Aesthetics and beauty are a very important aspect. We have created natural spaces overlooking water front and developed a conference centre, fully serviced apartments that can be rented for variable periods of time. We are also attracting supporting services such as cafes and the likes.

From the tenants firms view it is important that apartments and other services are available so that it becomes easier to accommodate their employees and visitors.

\subsection{Number of Jobs Created within the Immediate Community and the Country}

This is a straight forward measure of the technology park success. However, it also reflected the ability of the technology park management to effectively link the different stakeholders together. That is the ability of the technology park management to link universities and local labour market with tenant firms. One technology park manager explains:

We have developed a mechanism by which we can link job seekers with the companies within the park. But the more important aspect is that of university students training which can be replaced by a formal job opportunity. The relationship between universities and the parks' tenant firms is assumed to exist and function smoothly. However, this is not the case. Universities are sometimes distant and may not be able to gain access for training in the parks' tenant firms. In our capacity as park management we bring the different parties together and make sure that they see what is in it for them.

\subsection{Technology Transferred}

Technology transfer can take place in different ways. The usual is that through the mingling of different tenant firms within the park. Technology park management arranges regular meetings to hook up employees and managers of tenant firms together. In these informal meetings managers and employees from different firms but related or close 
industry can share experiences, discuss common obstacles and problems. This may lead to sharing of knowledge and technology. In many cases synergies are created and companies can benefit through the buying of services or product from other tent firms in the park. One technology park manger explains:

We set up regular activities every month. We do it in a way that the activities are informal and apart in time. The idea is to put everybody in an environment where they can have a chat, discuss their work, goals problems and so on.

The second way a technology park assists in transferring technology is through the provision of jobs and training for students, young graduates and highly skilled employees. Employees may have the opportunity to work with leading Australian or foreign firms for short projects or long term contracts which provides them with new knowledge, technology and managerial skills. When these employees leave the tenant firm, and join the workforce in the market they participate directly or indirectly in transferring knowledge, technology and management styles. At the same time knowledge can be transferred from the workforce to tenant firms within the park making it a two way process. One manager comments:

Foreign companies are attracted to this park because this city has been traditionally known to host [name of industry removed] industry. Proximity to the sea has always attracted [name of industry removed] industry to this city which meant that with time we have created a pool of skilled labour in this realm.

\section{Success Factors}

The interviews revealed a variety of factors that influence the success of the technology parks. The researcher was able to triangulate perspectives and to develop a more robust assessment of each technology park by comparing different perspectives across technology parks' management and tenant firms' management. However, differences in perceptions of success naturally translated into differences in perceived determinants of success. Cross-case comparison was the most useful tool in the researcher's induction of the determinants of success. At a basic level, it was found that successful technology parks had: 1. a risk taking "entrepreneurial" culture, 2. an autonomous park management that is independent of both university officials and government bureaucrats, 3 . an enabling environment, 4. a critical mass of companies that allows for synergies to arise within the technology park, 5. A shared vision among technology parks' stakeholders.

\subsection{A Culture of Risk Taking "Entrepreneurism"}

One of the major roles of a technology park is that of linking research, technology, capital and know-how to leverage entrepreneurial talent, accelerate the development of new technology-based firms, and speed up the commercialization of technology. Most mangers interviewed believed that innovation required a risk taking culture that rarely exists in universities or local/regional government institutions. One researcher/technology park manager commented:

the university [name of university removed] does not understand what we do. We are involved in leading technology exploration which is very risky in nature but can be very rewarding at the same time. They [university management] perceive what we do as risky. When they undertake their risk assessment every year they put us at the top of the list. I think that they are worried about the resources and grants and how they are being used and the legal implications of the process. This is why universities should not manage the park!

Another explained:

Universities; like any other government institution are mainly concerned with efficiencies and playing it safe. If they are not sure of the outcomes then they are not willing to take a risk. However, private sector firms are more likely to undertake much higher risk.

Another researcher further elaborated that:

We do not advocate taking risk for the sake of taking risk. It is risk that is managed professionally by the people who truly understand its nature!

Furthermore, despite universities interest in generating income from patents and attracting funds the main focus of universities remain knowledge creation and its dissemination. One manager/researcher explained that:

Before the technology park became independent, some university deans, who were brilliant researchers, worked at the technology park as associated deans. Their compensation came from the university and they were not paid any extra money from the technology park. In exchange for each new patent they came up with; the university paid them 1 dollar! That is one dollar for each patent created! This is just an example of how universities lacked an understanding of the importance of motivating researchers to create patents that can be commercialized and bring huge amount of money. How can we motivate researchers under these conditions? How can researchers excel at 
what they do? Now, since the park became independent of the university we utilise a totally different motivation system. Last year we sent some of our brilliant researchers on a two weeks payed vacation to an exotic resort overseas.

Government entities on the other hand tended to view technology parks as no more than real estate development. One technology park manager argued:

A very important distinction between the present management and the previous one (the present being market oriented and autonomous and the previous being the local government) is that the previous management treated the technology park as a real estate development. This meant that they were not concerned with the impact of the technology park on the economy, creating IP and knowledge, creating linkages between universities, research facilities and private companies whether start ups or international firms. The difference in enormous!

\subsection{An Autonomous Park Management}

In order to create a risk taking environment where participants have the freedom to try and fail managers agreed that technology parks' management should be independent from both the university and local/regional government bureaucrats. One manger commented:

Since the new management took lead of the technology park from the regional government things have changed dramatically. We operate on commercial basis just like any other firm in the market.

Another manager/researcher argued that:

Regional governments and universities cannot evaluate and manage the risks and potential benefits of establishing or funding technology-based start-ups. They inherently lack the knowledge to develop a rigorous appraisal system for a technology project. Because we understand the nature of what we do we can employ the right people and therefore can mange the risk effectively and efficiently.

This is not to say technology parks are totally independent from universities or the regional governments. In some cases universities undertook administrative support in the form of developing contracts and other HRM activities. This allowed the technology park management to focus on what is important. In addition universities are represented on the board of directors of the technology park so that the relationship is continued and an understanding of university interest is kept in consideration. One researcher argues that:

Technology based ventures often have social and environmental implications. They are inherently more risky than others and the management of risks calls for assessment techniques and vision.

\subsection{An Enabling Environment}

Most of the study participants agreed that an enabling environment in which the technology park operates can be detrimental to its success. According to the participants of the study there are numerous enablers to the success of a technology park which may include: the presence of knowledge workers and skilled labour in the immediate environment of the technology park, the availability of the right communication energy and real estate infrastructure, the availability of IP office within the technology parks.

With regards to skilled labour it is important that a pool of workers exists in the immediate environment and outer environment of the technology park. This was not problem for any of the technology parks involved in the study despite the fact that Australia faces an extreme shortage in skilled labour. One technology park manager explains:

This city has been a traditional location for ship builders in Australia. This meant a pool of skilled labour in this industry and related industries which helped us a lot in attracting the kind of companies that we have in the park.

In other parks the labour consisted mainly of researchers who were attracted by universities and research companies that are themselves tenants in the park. One technology park manager comments:

We rely heavily on researchers from the university [this university is linked formally to the park]. We also rely on postgraduate research students who undertake their research under the university but at the same time use research facilities and labs in tenant companies. This provides us with a big pool of knowledge workers.

With regards to the right infrastructure, it is important that the necessary infrastructure such as communication and energy are made available to tenant companies. Technology parks involved provided developed infrastructure that was used attract leading research and foreign companies to the park. One technology park business development manager explained that:

We have managed a major Australian communication firm to base its broad band internet services in the park. In exchange we promised them to the official provider for the park and its tenant firms. Indeed we gave them big fish! 
Foreign companies whose work required a high quality communication infrastructure and what can be better than a facility that is in the same vicinity of the firm (that is in the park).

\subsection{A Critical Mass of Leading Foreign Companies}

Participants agreed that a critical mass of companies in general and foreign companies specifically affords park and the region with a labour pool that is both broad and deep. This enables the region to draw more high-quality employers and companies that not only provide jobs but also increase the sophistication and expertise of the region's workforce through their research, use of technology, investment in employees and high standards. It also provides an environment in which company researchers, knowledge workers, and university professors can interact around ideas, creativity and entrepreneurship, thereby creating more knowledge, more innovation, and economic growth.

Another reason why the presence of internationally renowned firms is important is that these firms usually have established markets overseas therefore, guaranteeing availability of resources and markets for companies' outputs. One park manager commented:

The Australian market is limited in size, there is a shortage of skilled labour and more than $90 \%$ of Australian companies are SMEs. The presence of leading foreign companies guarantees that they will have their own established markets and will not rely totally on the Australian market. They bring in their capital, technology and managerial knowledge. At time they may even bring in their own employees.

This is not always the case however. To a certain extent it depends on the nature of the technology park and the rationale behind its establishment. For example, one of the smallest technology parks, which was not located in a major city and was located in a rural location focused on agricultural businesses and research. In this case the nature of Australian market, labour market reflected on the technology park. Australia faces a huge shortage in skilled labour in general and in agriculture specifically. The implication is that Australian agricultural businesses used capital investment and highly developed technology and highly productive workforce to compensate for labour shortage. The technology park itself was composed of mainly Australian SMEs that specialized in agriculture which managed to attract world class researchers from all over the world in order to solve the shortage problem.

\subsection{A Shared Vision}

Due to the nature of a technology park and the fact that numerous parties are involved in its creation and development; it is important that these parties have an agreement and understanding of what the technology park should do both in the short and long run. The aim is to link the strategies of the universities and the tenant firms with the city's/region's own self-vision of the future of the city/ region where the technology park resided. One manager argued that:

To seek a shared vision among senior stakeholders of what success in [city name] would look like in 3 years time and to begin the process of developing a strategy to achieve that vision.

Another manager noted that:

The direct involvement of senior stakeholders in strategy generation, created a motivation towards implementation of results that may have been lacking in a more extended but lower level process. In a way the process provided insights for all into how foresight approaches can be usefully adapted to a specific policy context to set in motion dynamic networking processes so vital for the regional innovation system.

\section{Conclusions}

This study used intensive interviewing of technology parks' managers and managers of tenant firms in these parks to explore critical success factors of four of Australia's' technology parks. The study showed that the success of a technology park depends primarily on the body or the institution that is managing the park. In general, participants agreed that universities focused on: research, students training and creating intellectual property (IP) whereas government bodies focused: on technology transfer, job creation and economic development. In addition, participants noted that universities had little understanding of market mechanisms such the commercialization of IP and concept development and testing while government bodies treated technology parks as real estate developments. The study also found that while the participants agreed on the previous success indicators of technology parks success; their emphasis on the importance of the different indicators varied.

The study found that an autonomous, private firm like management of the technology park is more likely to reach a better success considering the multiple stakeholders involved in the technology park. This is in contrast to the situation when universities managed technology parks here they focused solely on research and IP creation and government entities where the technology park was treated as a real estate development. This is evident by the fact 
that all four technology parks involved shifted from university and/or government control into an autonomous management that is independent from both the universities and the government.

The study found the following to be critical success factors of technology parks in Australia:

1. A culture of risk-taking "entrepreneurism": a technology park that is has a culture of risk taking and entrepreneurism is more likely to succeed and produce more innovation and IPs. 2. An autonomous park management that is independent of both university officials and government bureaucrats: a technology park that is managed by an independent, private firm-like management is more likely to adopt a risk taking culture and therefore produce more innovations and a higher commercialisation rate. 3. An enabling environment that encompasses some or all of the following: the presence of knowledge workers and skilled labour in the immediate environment of the technology park, the availability of the right communication energy and real estate infrastructure, the availability of IP office within the technology parks increase the likelihood of success of a technology park. 4. A critical mass of internationally renowned innovative companies, and finally 5. a shared vision among the technology park stakeholders.

\section{Recommendations}

Based on the previous conclusions the study makes the following recommendations:

1. To able to succeed technology parks management should nurture a culture entrepreneurship (risk taking and the freedom to fail). Successful innovation and commercialisation of IPs involves risk taking that is usually lacking in universities and government institutions especially the commercialisation side. The nature of technology parks requires such risk taking. However, this is a calculated risk that is managed by a professional management. 2 . Technology park management should be autonomous from both universities and the government. It should either be totally independent or has a very high degree of autonomy. A culture of risk taking that was described in the previous point can only be achieved if the technology park has a high degree of autonomy. If this autonomy can not be achieved then the motivational incentive systems used by universities and government bodies to manage the park should be substantially modified to match those of the private sector. 3 . Technology parks should provide and strive to build an enabling environment that attracts prospective tenants to the park. Communication infrastructure, real estate development of the park, proximity services can all add value to the park and can be detrimental to the decision of entry of prospective tenants. 4. Technology parks should try and build a critical mass of tenants firms which may help in creating synergies between these firms and therefore add value. Technology parks' management can adopt specific and targeted entry policy for prospective tenants that allows the technology park to choose tenants that will add to value to the technology park's stock of firms. Further, leading foreign firm should be targeted since they bring in technology, capital and new managerial styles. 5. Technology park management should aim to build a consensus or at least an understanding among the park stakeholders so that the benefits and value are maximized and all interests are served. Successful technology parks' management should make regular meeting and gatherings among tents of the park, government officials, and the community to open communication channels in order to build relationships at the grass root levels and help create a comprehensive and sustainable development on the long run where technology parks become a major player in this process.

\section{References}

Adegbite, O. (2001). Business incubators and small enterprise development: the Nigerian experience. Small Business Economics, 17, 157-166. http://dx.doi.org/10.1023/A:1011801018398

Akçomak, İ. (2009). Incubators as Tools for Entrepreneurship Promotion in Developing Countries. UNU-MERIT Research Workshop on Entrepreneurship, Technological Innovation, and Development, Maastricht, Netherlands.

Autto, E., \& Klofsten, M. (1998). A Comparative Study of Two European Business Incubators. Journal of Small Business Management, 36(1), 30-43.

Bachman, R., \& Schutt R. (2007). The Practice of Research in Criminology and Criminal Justice (3 ${ }^{\text {rd }}$ ed.). CA.:Sage.

Bakouros, Yiannis L., Mardas, Dimitri C., \& Varsakelis, Nikos C, (2002). Science Park, a high tech fantasy? An analysis of the science parks of Greece. Technovation, 22, 123-128. http://dx.doi.org/10.1016/S0166-4972(00)00087-0

Bardin, L. (1977). Análise de conteúdo. Paris: PUF.

Basile, A. (2011). Networking System and Innovation Outputs: The Role of Science and Technology Parks. International Journal of Business and Management, 6(5), 3-15. http://dx.doi.org/10.5539/ijbm.v6n5p3 
Bigliardi, B., Dormio, A. I., Nosella, A., \& Petroni, G. (2005). Assessing science parks' performances: directions from selected Italian case studies. Technovation (In press), 1-17.

Briggs, A., \& Watt, S. (2001). Technology and research parks. Report in 'Impacts of National Information Technology Environments on Business', American University, Washington, D.C.

Castells, M., \& Hall, P. G. (1994). Technopoles of the World: The making of 21st Century Industrial Complexes. New York: Routledge.

Chan, K. F., \& Lau, T. (2005). Assessing technology incubator programs in the science park: The good, the bad and the ugly. Technovation, 25(10), 1215-1228. http://dx.doi.org/10.1016/j.technovation.2004.03.010

Chan, K., Oerlemans, L., \& Pretorius, M. (2009). Explaining Mixed Results on Science Parks Performance: Bright and Dark Sides. South African Journal of Industrial Engineering, 20(2), 53-67

Charmaz, K. (2007). Constructing grounded theory: A practical guide through qualitative analysis. SAGE Publications.

Colombo, M. G., \& Delmastro, M. (2002). How effective are technology incubators? Evidence from Italy. Research Policy, 31(7), 1103-1123. http://dx.doi.org/10.1016/S0048-7333(01)00178-0

Drescher, D. (2001). Research parks: A brief overview of research parks for economic developers. http://www.unc.edu/depts/dcrpweb/courses/261/drescher/index.html, visited December 14, 2001.

Fazlzadeh, A., \& Moshiri, M. (2010). An Investigation of Innovation of Small Scale Industries Located in Science Parks of Iran. International Journal of Business and Management, 5(10), 148-154.

Gower, G. \& Harris, F. (1996). Evaluating British science parks as property investment opportunities. Journal of Property Valuation and Investment, 14(2), 24 - 37. http://dx.doi.org/10.1108/14635789610112646

Hackett, S. M., \& Dilts, D. M. (2004). A systematic review of business incubation research. Journal of Technology Transfer, 29, 55-82. http://dx.doi.org/10.1023/B:JOTT.0000011181.11952.0f

Hochschild, J. L. (2009). Conducting intensive interviews and elite interviews. Workshop on Interdisciplinary Standards for Systematic Qualitative Research. Washington D.C.: National Science Foundation.

Holbrook, A., \& Wolfe, D. (2002). eds. Knowledge, Clusters and Regional Innovation. McGill-Queen's. Montreal and Kingston.

Isaak, R. (2009). From Collective Learning to Silicon Valley Replication: The limits to Synergistic Enterpreneurship in Sophia Antipolis. Research in International Business and Finance, 23(2), 134-143. http://dx.doi.org/10.1016/j.ribaf.2008.03.006

Kvale, S. (1996). Interviews: An introduction to qualitative research interviewing. CA.: Thousand Oaks, Sage.

Lalkaka, R. (2006). Technology Business Incubation: A Toolkit on Innovation in Engineering, Science and Technology. Paris: UNESCO Publishing.

Lendner, C. (2004). University involvements in university business incubators and their impact on the start-ups. $3 r d$ International GET UP Workshop on University-based Start-ups, University of Applied Sciences, Jena.

Lendner, C. (2007). University technology transfer through university business incubators and how they help start-ups', in Therin, F. Ed. Edward Elgar, Handbook of Research on Techno-entrepreneurship. Cheltenham, 163-9.

Lin, C., Jiang, J. L., Wu, Y. J., \& Chang, C. C. (2011). Assessment of commercialization strategy using R\&D capability. Industrial Management \& Data Systems, 111(3), 341-69. http://dx.doi.org/10.1108/02635571111118251

Lindelof, P., \& Lofsten, H. (2002). Growth, management and financing of new technology based firms-assessing value-added contributions of firms located on and off science parks. Omega, 30, 143-154. http://dx.doi.org/10.1016/S0305-0483(02)00023-3

Lofland, J., \& Lofland, L. (1984). Analyzing social settings: A guide to qualitative observation and analysis, Belmont. CA: Wadsworth.

Lofland, J., \& Lofland, L. (1995). Analyzing social settings: A guide to qualitative observation and analysis $\left(3^{\text {rd }}\right.$ ed.). Belmont. CA: Wadsworth.

Malairaja, C., \& Zawdie, G. (2008). Science parks and university-industry collaboration in Malaysia. Technology Analysis \& Strategic Management, 20(6), 727-739. http://dx.doi.org/10.1080/09537320802426432 
Mian Sarfraz A. (1997). Assessing and managing the university technology business incubator: an integrative framework. Journal of Business Venturing, 12, 251-285. http://dx.doi.org/10.1016/S0883-9026(96)00063-8

Mian, Sarfraz A. (1996). Assessing value-added contributions of university technology business incubators to tenant firms. Research Policy, 25(3), 325-335. http://dx.doi.org/10.1016/0048-7333(95)00828-4

Peng, M. W., \& Heath, P. (1996). The Growth of the Firm in Planned Economies in Transition: Institutions, Organizations, and Strategic Choice. Academy of Management Review, 21(2), 492-528.

Phan, P. H., Siegel, Donald, S., \& Wright, M. (2005). Science parks and incubators: observations, synthesis and future research. Journal of Business Venturing, 20, 165-182. http://dx.doi.org/10.1016/j.jbusvent.2003.12.001

Rasmussen, E. (2008). Government instruments to support the commercialization of university research: lessons from Canada. Technovation, 28, 506-17. http://dx.doi.org/10.1016/j.technovation.2007.12.002

Reinharz, S. (1992). Feminist Methods in Social Research. New York: Oxford University Press.

Rubin, H., \& Rubin, I. (1995). Qualitative interviewing: The art of hearing data. CA.: Thousand Oaks, Sage.

Sherman, H. D. (1999). Assessing the intervention effectiveness of business incubation programmes on new business start-ups. Journal of Developmental Entrepreneurship, 4(2), 117-133.

Siegel, D. S., Westhead, P., \& Wright, M. (2003). Assessing the impact of university science parks on research productivity: exploratory firm-level evidence from the United Kingdom. International Journal of Industrial Organization, 21, 1357-1369. http://dx.doi.org/10.1016/S0167-7187(03)00086-9

Smilor, R. W., \& Gill, M. D. Jr. (1986). The new business incubator: linking talent, technology, capital, and know-how. Massachusetts: Lexington.

Somsuk, N., Wonglimpiyarat, J., \& Laosirihongthong, T. (2012). Technology business incubators and industrial development: resource-based view. Industrial Management \& Data Systems, 112(2), 245-267. http://dx.doi.org/10.1108/02635571211204281

Sun, H., Ni, W., \& Leung, J. (2007). Critical success factors for technological incubation: Case study of Hong Kong science and technology parks. International Journal of Management, 24(2), 346-363.

UNESCO. (2012). Science policy and capacity building. Retrieved from: http://www.unesco.org/new/en/natural-sciences/science-technology/university-industry-partnerships/science-pa rks-around-the-world/ Accessed 11- 4- 2012

Venckuviene, V., \& Snieska, V. (2010). Venture capital tool in fostering innovativeness of tenants in science and technology park: Lithuanian Case, economics and Management. ISSN 1822-6515.

Walsham, G. (2006). Doing Interpretive Research. European Journal of Information Systems, 15(3), 320-330. http://dx.doi.org/10.1057/palgrave.ejis.3000589

Wolfe, D., \& Gertler, M. (2003). Lessons from the ISRN study of cluster development, in Clusters old and new: The transition to a knowledge economy in Canada's regions. Ed. D. A. Wolfe. Kingston: School of Policy Studies, Queen's University and McGill-Queen's University Press, 1-36.

Wood, J. (2003). Australia: an underperforming knowledge nation? Journal of Intellectual Capital, 4(2), 144-164. http://dx.doi.org/10.1108/14691930310472785 